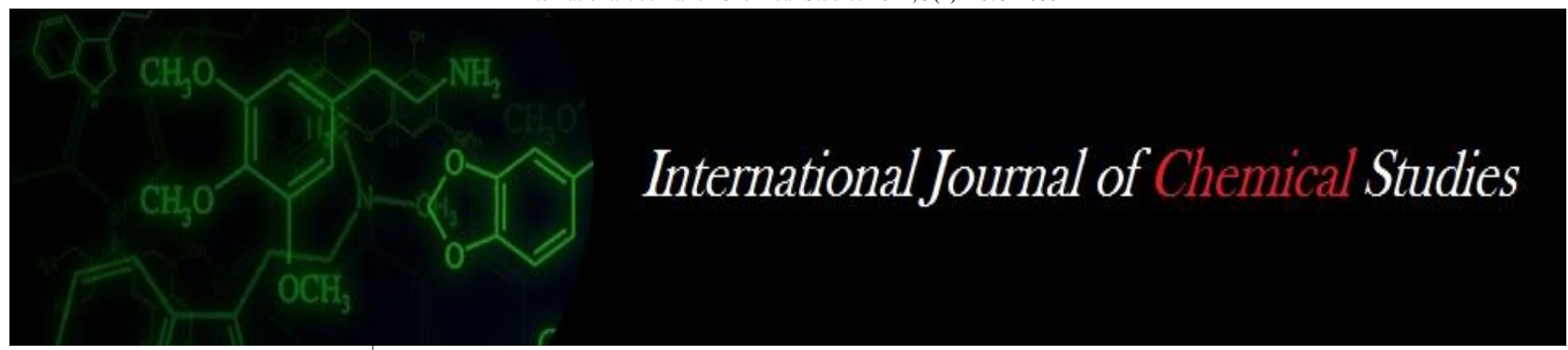

P-ISSN: 2349-8528

E-ISSN: 2321-4902

www.chemijournal.com

IJCS 2021; 9(1): 1675-1680

(C) 2021 IJCS

Received: $15-10-2020$

Accepted: 27-11-2020

\section{Biradar SD}

Department of Food Science and Technology, Post Graduate

Institute Mahatma Phule Krishi

Vidyapeeth, Rahuri

Maharashtra, India

\section{Kotecha PM}

Department of Food Science and Technology, Post Graduate

Institute Mahatma Phule Krishi

Vidyapeeth, Rahuri

Maharashtra, India

\section{Godase SN}

Department of Food Science and Technology, Post Graduate

Institute Mahatma Phule Krishi

Vidyapeeth, Rahuri

Maharashtra, India

\section{Chavan UD}

Department of Food Science and Technology, Post Graduate

Institute Mahatma Phule Krishi

Vidyapeeth, Rahuri

Maharashtra, India

\section{Corresponding Author:}

\section{Biradar SD}

Department of Food Science and Technology, Post Graduate Institute Mahatma Phule Krishi Vidyapeeth, Rahuri

Maharashtra, India

\section{Studies on nutritional quality of cookies prepared from wheat flour and little millet}

\author{
Biradar SD, Kotecha PM, Godase SN and Chavan UD
}

DOI: https://doi.org/10.22271/chemi.2021.v9.i1x.11466

\begin{abstract}
The present research work was carried out to explore the possibility of utilization of underutilized but highly nutrient rich little millet in cookies. Preliminary experiments were carried out to find out optimum level of little millet flour with wheat flour for the preparation of quality cookies. The quality cookies were prepared from $20 \%$ wheat flour and $80 \%$ little millet flour (WLF80). The selected treatments were packed in LDPE and PP and stored at ambient $\left(30 \pm 4^{\circ} \mathrm{C}\right)$ for 90 days to study their storage feasibility. Chemical composition of the fresh cookies prepared from $20 \%$ wheat flour and $80 \%$ little millet flour (WLF80) showed that moisture content was $4.26 \%$, protein $8.40 \%$, crude fat $29.10 \%$, crude fiber $6.46 \%$, carbohydrates $67.48 \%$ and iron $8.42 \mathrm{mg} / 100 \mathrm{~g}$. The sensory evaluation of cookies was carried out regularly at an interval of one month for 3 month during storage. The results on overall acceptability score of cookies are influenced by storage. The results indicated that score for overall acceptability of cookies decreased for control from7.40 to 7.20 in LDPE and from 7.30 to 6.80 in PP as storage period get increased. For WLF80 treatment score decreases from 7.40 to 7.10 in LDPE and 7.20 to 6.70 in PP was observed for 90 days of storage. Storage study of cookies showed that the cookies prepared by incorporation of wheat flour and little millet flour can be stored up to 3 month in LDPE with minimum losses in sensory, nutritional and textural characteristics than PP. There was no significant difference in protein, crude fiber and iron content with advancement of storage period during 3 month. The cookies were found to be acceptable up to 3 month storage at ambient temperature. The total cost of production of cookies prepared from wheat flour and little millet flour (WLF80) for $1 \mathrm{~kg}$ was Rs. 201 /-
\end{abstract}

Keywords: Little millet, cookies, nutritional value, organoleptic properties

\section{Introduction}

There is a growing awareness among the consumers regarding the constituents that affect health both positively and negatively. The number of such health conscious consumers is fast increasing and so is the health food industry. New foods with new health claims are flooding the market to meet the diverse demands of consumers. However, still there is ample scope to enhance the nutritional value of cookies both quantitatively and qualitatively using nutritious food ingredients. In this regard, there are several food ingredients with exceptional nutritional qualities because of their nutraceutical and nutritional components, such as millets, oil seeds, condiments and other novel ingredients. Value addition to existing foods with such ingredients is a simple and feasible way of enhancing nutritional values of foods and in turn the health benefits.

Millets have been in food use since time immemorial and an array of traditional foods are prepared across rural India. However, food use of millets is fast decreasing due to several reasons. There is therefore a need to revive these important groups of health promoting foods to enhance nutritional quality of diets of consumers. Among the millets little millet is one of minor millet crop and called by several names such as Save/Savi in Kannada, Kutaki in Hindi, Samai in Tamil, Sama in Telagu, Sava in Marathi, Chama in Malayalam, Gajro in Gujrati, Kangani in Bangali and Swank in Punjabi. Little millet is oldest food grain known to mankind and possibly the first cereal grain used for domestic purpose. It forms the main stay of the dietary nutritional requirements. Nutritional composition of little millet is fat $(4.7 \mathrm{~g})$, crude fiber $(7.7 \mathrm{~g})$, iron $(9.3 \mathrm{mg}$ ) and phosphorus $(220 \mathrm{mg})$ per $100 \mathrm{~g}$ which is comparable to cereals and other millets (Gopalan et al., 2010). Dietary fiber content of little millet is the contributing factor for its low glycaemic index and a recent study conducted on little millet indicated that it exhibits hypoglycaemic effect due to its higher proportion of dietary fiber 
(Itagi et al., 2013) ${ }^{[11]}$. Little millet is perhaps one more addition to the proliferating list of healthy foods, owing to its nutritional superiority. With the modern people chasing ready to cook food items, the nutritive minor millets are being faded into oblivion. Potential minor millets like little millet can be woven in the fabric of daily diet. Regular consumption of little millet is very beneficial for postmenopausal women suffering from signs of cardiovascular disease, like high blood pressure and high cholesterol level. Additionally, it can blend with most of traditional and novel foods without imparting any flavours of its own. Hence, in the present study little millet was chosen to enhance the nutrient composition of cookiesin terms of dietary fiber and other nutrients

The cookie formula consists of refined flour, hydrogenated fat, sugar and other additives. It is well documented that most of the ingredients used in commercial cookies lack important nutrients. The refined flour lacks in dietary fiber and micronutrients which are important health promoting components. The hydrogenated fat comprises of trans-fats which have proven to be harmful to human health. Recognizing the negative health effects of trans-fats many countries have banned the trans-fats in foods and have recommended zero tolerance to trans-fats in foods for infants and other vulnerable groups. Nutrition labeling to indicate the trans-fats content is made mandatory in many countries. The bakery industry has been steadily growing in the country, being the largest among the processed food industries. The two major bakery industries namely bread and biscuits account for almost 82 per cent of the total bakery products. India is recognized to be the second largest producer of cookies next only to the United States of America with annual production of which was 7.40 lakh metric tonnes in 1997-98 which has escalated to 17.14 lakh metric tonnes in 2005-2009 (Agrawal, 1990) [3]. Among the bakery products biscuits command wide popularity in rural as well as urban areas among people of all age groups (Agrawal, 1990) ${ }^{[3]}$. The demand for processed foods is ever increasing due to the technological, industrial and economic advances of the developing societies of the world including India.
Materials and Methods

Ingredients: The major ingredients for the preparation of products were little millet procured from Zonal Agriculture Research Station, Kolhapur. The wheat flour was procured from local market.

Packaging material: The packaging material viz., LDPE and PP bags were procured from local market and used for packaging of cookies for storage study.

Treatment details: The little millet cookies were prepared by using different levels of little millet flour with wheat flour as shown below:

Table 1: Treatment details for preparation of little millet cookies

\begin{tabular}{|c|c|c|}
\hline Treatments & Wheat flour (\%) & Little millet flour (\%) \\
\hline $\mathrm{T}_{0}($ Control) & 100 & 0 \\
\hline $\mathrm{T}_{1}$ & 90 & 10 \\
\hline $\mathrm{T}_{2}$ & 80 & 20 \\
\hline $\mathrm{T}_{3}$ & 70 & 30 \\
\hline $\mathrm{T}_{4}$ & 60 & 40 \\
\hline $\mathrm{T}_{5}$ & 50 & 50 \\
\hline $\mathrm{T}_{6}$ & 40 & 60 \\
\hline $\mathrm{T}_{7}$ & 30 & 70 \\
\hline $\mathrm{T}_{8}$ & 20 & 80 \\
\hline $\mathrm{T}_{9}$ & 10 & 90 \\
\hline $\mathrm{T}_{10}$ & 0 & 100 \\
\hline $\mathrm{SE} \pm$ & 0.055 & 0.056 \\
\hline $\mathrm{CD}$ at $5 \%$ & 0.163 & 0.167 \\
\hline
\end{tabular}

\section{Method \\ Procedure for preparation of little millet flour}

The little millet grains were cleaned to remove extraneous matter and taken in small bowel and then attached to the electric decorticator to remove brans. The dried debraned little millet grains were grinded in to flour and passed through sieve of 80 mesh to get uniform flour.

\section{Preparation of little millet flour cookies}

The cookies were prepared using standard levels of ingredients as per the traditional creaming process (Fig1.)

Hydrogenated vegetable fat and powdered sugar mixed thoroughly

$$
\downarrow
$$

Wheat flour + little millet flour + Sodium bicarbonate + ammonium bicarbonate

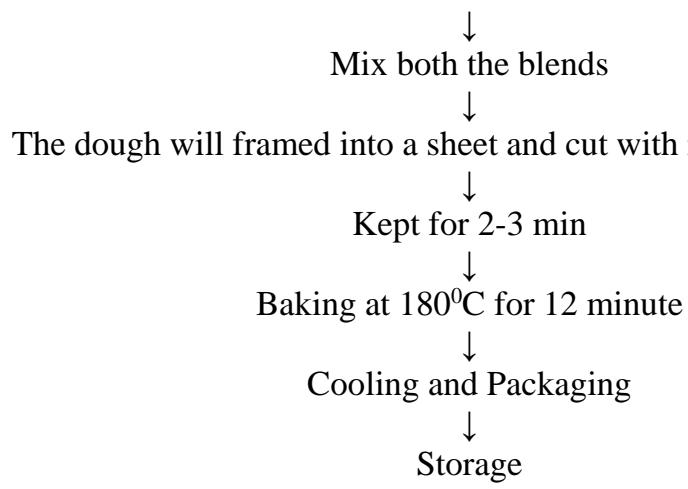

Fig 1: Flow chart for preparation of little millet cookies

\section{Physical characteristics of raw material}

The raw material little millet grains were analyzed for different physical characteristics like thousand kernel weight, bulk density and colour.

\section{Chemical properties of raw materials, cookies}

Chemical constituents like moisture, fat, protein, carbohydrate, crude fiber and minerals like phosphorous and iron content of raw material, cookies were determined as per the standard procedure.

Physico-chemical analysis of raw material, cookies The method described in A.O.A.C. (2000) ${ }^{[1,2]}$ for determining moisture was used. The protein content of cookies and biscuits was estimated by determining total nitrogen content using standard Micro-Kjeldhal method and fat content of the 
cookies and biscuits estimated by the soxhlet method A.A.C.C (2000) ${ }^{[1]}$. The crude fiber content in the products was estimated by A.A.A.C. (2000) ${ }^{[1]}$. The carbohydrate content in the selected cookies were obtained by subtracting from 100, the sum of values of moisture, protein and fat content per $100 \mathrm{~g}$ of the sample (Raghuramulu et al., 1993) ${ }^{[18]}$. Phosphorous and iron were analyzed using atomic absorption spectrometry (AAS). These methods give a good precision and accuracy (Ojeka and Ayodele 1995.) ${ }^{[16]}$.

\section{Packaging and storage of little millet cookies}

The selected treatments of little millet cookies were packed in LDPE and PP and stored at ambient $\left(30+4^{\circ} \mathrm{C}\right)$ for 3 months. The samples were drawn at an interval of 1 month and evaluated for chemical and sensory quality.

\section{Sensory evaluation of cookies}

Sensory evaluation of little millet cookies was carried on 9 point hedonic scale. The average scores of the ten judges for different quality characteristics viz. Colour and appearance, flavour, texture, taste and overall acceptability were recorded.

\section{Statistical analysis}

All experiments were carried out by using Factorial Completely Randomized Design (FCRD). The results obtained in the present investigation were analyzed for the statistical significance according to the procedure given by Rangaswamy (2010) ${ }^{[19]}$.

\section{Results and Discussion \\ Physical characteristics of raw materials}

Table 2: Physical characteristics of raw materials

\begin{tabular}{|c|c|}
\hline Physical parameter & Little millet \\
\hline Colour & Dull whitish \\
\hline Weight of 1000 seeds $(\mathrm{g})$ & 2.10 \\
\hline Bulk density $(\mathrm{g} / \mathrm{ml})$ & 1.51 \\
\hline True density $(\mathrm{g} / \mathrm{ml})$ & 2.81 \\
\hline Porosity $(\%)$ & 46.26 \\
\hline
\end{tabular}

The seed colour was dull whitish which indicated good quality. Bulk and true densities of little millet were low. Bulk density of seeds was found to be $1.51 \mathrm{~g} / \mathrm{ml}$, while the true density was $2.81 \mathrm{~g} / \mathrm{ml}$. The variations in density of little millet may be due to random harvesting of little millet at different maturity stages. This factor is important because it determines the capacity of storage, packaging and transport systems (James 2005) ${ }^{[4]}$. The per cent porosity of sample was found to be moderate i.e. 46.26 per cent. Porosity depends on size, shape and boldness of seeds. It must be noted that porosity of the mass of seeds determines the resistance to air flow during aeration and drying procedures.

\section{Chemical characters of raw materials}

The results obtained for chemical characteristics of Wheat flour and little millet flour are presented here:

Table 3: Chemical characters of raw materials

\begin{tabular}{|c|c|c|}
\hline Chemical constituent & Wheat flour & Little millet flour \\
\hline Moisture (\%) & 12.2 & 11.59 \\
\hline Protein (\%) & 11.2 & 7.70 \\
\hline Fat (\%) & 1.7 & 4.70 \\
\hline Crude fiber (\%) & 1.9 & 7.60 \\
\hline Carbohydrates (\%) & 69.4 & 67.00 \\
\hline Phosphorus (mg/100g) & 48 & 220.00 \\
\hline Iron (mg/100g) & 355 & 9.30 \\
\hline
\end{tabular}

*Each value is the average of three determinations

Chemical characters of various raw materials are comparable with findings reported by other scientist Tosco, (2004). These values are also comparable with Gopalan, et al., (2010). Similar conclusions have been drawn by Bushway, et al., $(1981)^{[7]}$, and Salazar, et al., (2011) ${ }^{[22]}$.

\section{Sensory evaluations of fresh little millet cookies}

The organoleptic evaluation of cookies prepared by different combination of little millet flour and wheat flour were carried out. Little millet cookies were prepared and presented to panel of ten judge for assessing the quality and acceptability of product. Organoleptic evaluation of cookies was carried out using a 9 point hedonic scale of sensory characteristics such as colour, flavour texture, taste and overall acceptability. The score obtained for sensory evaluation for little millet flour and wheat flour cookies are shown in Table 4.little millet and wheat flour cookies (20 wheat flour: 80little millet flour)were found the best for preparation of little millet and wheat flour cookies of good quality and stored at ambient temperature (30 $\pm 4^{\circ} \mathrm{C}$ ) for 3 month. Organoleptic quality parameters of a product assume pivotal role in anticipating the consumer response to the product (Rey 2006) ${ }^{[21]}$. Colour and appearance uniformity are vital components of visual quality of fresh as well as processed foods and play a major role in consumer choice (Alistair 2005) ${ }^{[4]}$. Flavour being a combination of taste, smell and mouth feel, has multifaceted impact on sensory quality of a product (Amerine, et al., 1980) ${ }^{[5]}$. Overall acceptability of product is a function of various factors including colour and appearance, flavour, texture and taste. Amongst all samples for both cookies containing 80 per cent little millet and 20 per cent wheat flour combination was found to be more acceptable. Singh et al., (2000) ${ }^{[26]}$ reported overall acceptability of product like cookies is a function of various factors including colour and appearance, flavour, texture and taste in the soy fortified biscuits storage. Gupta and Singh (2005) ${ }^{[10]}$ reported overall acceptability of biscuits containing colour and appearance, flavour, texture and taste which gives overall acceptance by considering above all attributes.

Selection of best combination for preparation of little millet fortified cookies: On the basis of organoleptic properties (colour and appearance, flavour, texture, taste and overall acceptability) the best combination from wheat and little millet flour was 20:80. For the storage study these combinations with control (100\% wheat flour) were selected and the cookies prepared from them used for further storage study. During storage study their nutritional composition, organoleptic properties and microbial quality were analysed using standard procedures. 
Table 4: Sensory evaluation of fresh wheat and little millet flour cookies

\begin{tabular}{|c|c|c|c|c|c|c|}
\hline \multirow{2}{*}{ Sample code } & \multicolumn{6}{|c|}{ Sensory attributes* } \\
\hline & Colour and appearance & Flavour & Texture & Taste & Overall acceptability & Rank \\
\hline $\mathrm{WLF}_{0}$ (Control) & 6.5 & 6.5 & 6.5 & 6.5 & 6.5 & 10 \\
\hline $\mathrm{WLF}_{10}$ & 6.8 & 6.7 & 6.5 & 6.5 & 6.62 & 9 \\
\hline $\mathrm{WLF}_{20}$ & 7.0 & 6.6 & 6.5 & 6.5 & 6.65 & 8 \\
\hline $\mathrm{WLF}_{30}$ & 7.0 & 6.7 & 6.7 & 6.8 & 6.8 & 7 \\
\hline $\mathrm{WLF}_{40}$ & 7.0 & 6.7 & 6.8 & 6.8 & 6.82 & 6 \\
\hline $\mathrm{WLF}_{50}$ & 7.1 & 7.0 & 7.0 & 7.0 & 7.02 & 4 \\
\hline $\mathrm{WLF}_{60}$ & 7.2 & 7.2 & 7.2 & 7.2 & 7.2 & 3 \\
\hline WLF70 & 8.2 & 8.3 & 8.2 & 8.3 & 8.25 & 2 \\
\hline $\mathrm{WLF}_{80}$ & 9.0 & 9.0 & 9.0 & 9.0 & 9.0 & 1 \\
\hline $\mathrm{WLF}_{90}$ & 7.0 & 6.9 & 7.0 & 6.8 & 6.92 & 5 \\
\hline $\mathrm{WLF}_{100}$ & 6.1 & 6.3 & 6.5 & 6.4 & 6.32 & 11 \\
\hline Mean & 7.17 & 7.08 & 7.08 & 7.07 & 7.10 & - \\
\hline S.E.t & 0.04 & 0.03 & 0.05 & 0.04 & 0.03 & - \\
\hline C.D at $5 \%$ & 0.12 & 0.11 & 0.16 & 0.13 & 0.10 & - \\
\hline
\end{tabular}

*Maximum score out of 9 whereas,

$\mathrm{WLF}_{0}=(100$ wheat: 0 little millet flour $)$,

$\mathrm{WLF}_{20}=$ (80 wheat: 20 little millet flour $)$,

$\mathrm{WLF}_{40}=(60$ wheat: 40 little millet flour $)$,

$\mathrm{WLF}_{60}=$ (40 wheat: 60 little millet flour $)$,

$\mathrm{WLF}_{80}=(20$ wheat: 80 little millet flour $)$,

$\mathrm{WLF}_{100}=(0$ wheat: 100 little millet flour $)$

\section{Nutritional value changes in little millet cookies during storage}

The average values of fresh cookies(100\% wheat) was moisture increased for treatment WLF0 from 4.20 to 4.29 per cent in LDPE and 4.22 to 4.32 per cent in PP was observed for 90 days of the storage. The sample WLF80 showed increase in the moisture content 4.26 to 4.37 per cent in LDPE and 4.28 to 4.39 per cent in PP. Protein decreased for WLF0treatment from 13.03 to 12.95 per cent in LDPE and from 13.01 to 12.93 per cent in PP was observed for 90 days of storage. The sample WLF80showed from 8.40 to 8.26 per cent in LDPE and from 8.38 to 8.24 per cent in PP. Fat decreased for treatment WLFOfrom 26.48 to 26.38per cent in LDPE and from 26.46 to 26.35 per cent in PP was observed for 90 days of storage. The sample WLF80showed from 29.10 to 28.96 in LDPE and from 29.08 to 28.95 in PP. Crude fiber decreased for treatment WLF0from 1.85 to 1.75 per cent in
LDPE and from 1.83 to 1.73 per cent in PP was observed for 90 days of storage. The sample WLF80showed crude fibre content 6.46 to 6.33 per cent in LDPE and from 6.43 to 6.32 per cent in PP. Carbohydrates decreased for WLFOfrom 70.40 to 70.34 per cent LDPE and from 70.37 to 70.31 per cent in PP was observed for 90 days of storage. The sample WLF80showed carbohydrate content 67.48 to 67.37 per cent in LDPE and from 67.46 to 67.36 per cent in PP. Iron decreased for treatment WLF0from 4.8 to $4.1 \mathrm{mg} / 100 \mathrm{~g}$ in LDPE and 4.6 to $3.98 \mathrm{mg} / 100 \mathrm{~g}$ in PP was observed for 90 days. The sample WLF80showed from 8.42 to $8.34 \mathrm{mg} / 100 \mathrm{~g}$ in LDPE and from 8.39 to $8.34 \mathrm{mg} / 100 \mathrm{~g}$ in PP (Table 5).Protein, fat, crude fiber, carbohydrate, and iron decreased in ambient temperature during storage period of 3 month. The decrease in moisture, protein, fat, carbohydrate, crude fiber and iron was more rapid in the samples stored in PP than LDPE during the storage period.

Table 5: Nutritional changes in little millet cookies during storage at ambient temperature

\begin{tabular}{|c|c|c|c|c|c|c|}
\hline Treatment & Moisture (\%) & Protein $(\%)$ & Fat $(\%)$ & Crude fiber (\%) & Carbohydrate (\%) & Iron (mg/100g) \\
\hline \multicolumn{7}{|l|}{ Treatment } \\
\hline $\mathrm{T}_{0}: \mathrm{WLF}_{0}$ & 4.26 & 12.96 & 26.39 & 1.77 & 70.34 & 2.62 \\
\hline $\mathrm{T}_{1}: \mathrm{WLF}_{80}$ & 4.34 & 8.29 & 29.00 & 6.37 & 67.40 & 7.24 \\
\hline S.E. \pm & 0.009 & 0.009 & 0.009 & 0.009 & 0.009 & 0.009 \\
\hline $\mathrm{CD}$ at $5 \%$ & 0.027 & 0.028 & 0.028 & 0.027 & 0.028 & 0.028 \\
\hline \multicolumn{7}{|c|}{ Packaging material } \\
\hline $\mathrm{P}_{0:}$ LDPE & 4.29 & 10.63 & 27.70 & 4.07 & 68.88 & 4.94 \\
\hline $\mathrm{P}_{1:} \mathrm{PP}$ & 4.31 & 10.62 & 27.68 & 4.06 & 68.85 & 4.91 \\
\hline S.E. \pm & 0.009 & 0.009 & 0.009 & 0.009 & 0.009 & 0.009 \\
\hline $\mathrm{CD}$ at $5 \%$ & 0.027 & 0.027 & 0.027 & 0.027 & 0.028 & 0.028 \\
\hline \multicolumn{7}{|l|}{ Storage period } \\
\hline $\mathrm{C}_{1}: 30$ Days & 4.27 & 10.67 & 27.73 & 4.10 & 68.89 & 4.97 \\
\hline $\mathrm{C}_{2:} 60$ Days & 4.30 & 10.62 & 27.69 & 4.07 & 68.87 & 4.93 \\
\hline $\mathrm{C}_{3}$ : 90 Days & 4.33 & 10.59 & 27.66 & 4.03 & 68.84 & 4.89 \\
\hline S.E. \pm & 0.011 & 0.012 & 0.012 & 0.011 & 0.012 & 0.012 \\
\hline $\mathrm{CD}$ at $5 \%$ & 0.033 & 0.034 & 0.034 & 0.033 & 0.034 & 0.034 \\
\hline \multicolumn{7}{|l|}{ Interaction } \\
\hline $\mathrm{T}_{0} \mathrm{P}_{0} \mathrm{C}_{1}$ & 4.23 & 13.00 & 26.43 & 1.80 & 70.38 & 2.67 \\
\hline $\mathrm{T}_{0} \mathrm{P}_{0} \mathrm{C}_{2}$ & 4.26 & 12.97 & 26.41 & 1.78 & 70.36 & 2.64 \\
\hline $\mathrm{T}_{0} \mathrm{P}_{0} \mathrm{C}_{3}$ & 4.27 & 12.95 & 26.38 & 1.75 & 70.34 & 2.60 \\
\hline $\mathrm{T}_{0} \mathrm{P}_{1} \mathrm{C}_{1}$ & 4.25 & 12.99 & 26.42 & 1.79 & 70.35 & 2.65 \\
\hline $\mathrm{T}_{0} \mathrm{P}_{1} \mathrm{C}_{2}$ & 4.27 & 12.96 & 26.37 & 1.76 & 70.33 & 2.61 \\
\hline
\end{tabular}




\begin{tabular}{|c|c|c|c|c|c|c|}
\hline $\mathrm{T}_{0} \mathrm{P}_{1} \mathrm{C}_{3}$ & 4.29 & 12.93 & 26.35 & 1.74 & 70.31 & 2.57 \\
\hline $\mathrm{T}_{1} \mathrm{P}_{0} \mathrm{C}_{1}$ & 4.30 & 8.35 & 29.05 & 6.42 & 67.45 & 7.29 \\
\hline $\mathrm{T}_{1} \mathrm{P}_{0} \mathrm{C}_{2}$ & 4.33 & 8.30 & 29.01 & 6.38 & 67.42 & 7.26 \\
\hline $\mathrm{T}_{1} \mathrm{P}_{0} \mathrm{C}_{3}$ & 4.37 & 8.26 & 28.96 & 6.33 & 67.37 & 7.22 \\
\hline $\mathrm{T}_{1} \mathrm{P}_{1} \mathrm{C}_{1}$ & 4.31 & 8.34 & 29.04 & 6.41 & 67.41 & 7.27 \\
\hline $\mathrm{T}_{1} \mathrm{P}_{1} \mathrm{C}_{2}$ & 4.35 & 8.28 & 29.00 & 6.37 & 67.39 & 7.23 \\
\hline $\mathrm{T}_{1} \mathrm{P}_{1} \mathrm{C}_{3}$ & 4.39 & 8.24 & 28.95 & 6.32 & 67.36 & 7.18 \\
\hline S.E. \pm & 0.02 & 0.09 & 0.02 & 0.02 & 0.02 & 0.10 \\
\hline $\mathrm{CD}$ at $5 \%$ & 0.07 & 0.28 & NS & 0.07 & NS & 0.29 \\
\hline
\end{tabular}

Where, $\mathrm{WLF}_{0}=100 \%$ wheat, $\mathrm{WLF}_{80}=20 \%$ wheat and $80 \%$ little millet flour. LDPE $=$ Low Density Polyethylene, $\mathrm{PP}=$ Polypropylene

Mirsaeedghazi, et al., (2008) ${ }^{[15]}$ reported that increase of protein in dough causes greater consistency of dough. The interaction including physical and chemical forces among protein molecules play key role on the rheological properties (Shiau and Yeh, 2001) ${ }^{[25]}$. The increase in protein content is acceptable for better rheological characteristics.

Sharoon et al., (2014) ${ }^{[24]}$ reported considerable increment the moisture content in all cookies with increasing storage duration. This increase was primarily due to packaging material (polythene bags).

Moreover, cookies absorbed moisture from surrounding atmosphere due to hygroscopic behaviour of wheat flour. An increase in moisture contents of cookie samples during storage has also been reported by Leelavathi and Rao (1993) ${ }^{[13]}$, Rao, et al., (1995) ${ }^{[20]}$ Pasha, et al., (2002) ${ }^{[17]}$, Butt, et al., (2004) [8] and Shariff, et al., (2005) [23] either due to atmosphere or packaging materials.

\section{Conclusion}

These results indicates that $\mathrm{CMKF}_{50}$ cookies (20 per cent wheat flour and 80 per cent little millet flour) with constant levels of other ingredients stored at ambient temperature had better acceptability till $90^{\text {th }}$ day. It is evident from all the physico-chemical properties thatCMKF $\mathrm{F}_{50}$ cookies $(20$ per cent wheat flour and 80 per cent little millet flour are the best in LDPE than PP for preparation of little millet cookies of good quality

\section{References}

1. AACC. Official Methods of Analysis of AACC International, American Association of Cereal Chemists, Washington D.C 2000.

2. OAC. Offical Methods of Analyasis, 18th edition. Association of Official Analytical Chemist. Washignton DC 2000, 454.

3. Agrawal SR. Prospects for small-scale biscuit industry in the nineties. Indian Food Indus 1990;9:19-21.

4. Alistair SG. Postharvest Handling and Preparation of Foods for Processing. In Food Processing Handbook. Edited by James G.B. Wiley-VCH Verlag GmbH and Co. KGaA, Weinheim 2005, 87.

5. Amerine MA, Pangborn RM, Roessler EB. Principles of Sensory Evaluation of Food. Academic Press. New York 1980, 549.

6. Anonymous. Annual Report of All India Coordinated Research Project, ICAR, New Delhi 2009.

7. Bushway AA, Belyea PR, Bushway RJ. Foxtail millet as a source of oil, polysaccharide, and protein. Journal of Food Science 1981;46:1349-1350.

8. Butt MS, Sharif K, Mukhtar T, Rasool J. Storage studies of red palm oil fortified cookies. Nutr. Food Sci 2004;34(6):272-76.

9. Gopalan C, Ramashastri BV, Balasubramanium SC. Nutritive Value of Indian Foods. National Institute of Nutrition, ICMR, Hyderabad 2006, 47-69.
10. Gupta HO, Singh NN. Preparation of wheat and quality protein maize based biscuit and their storage, protein quality and sensory evaluation. J Food Sci. Technol 2005;42(1):43-46.

11. Itagi S, Naik R, Yenagi N. Versatile little millets therapeutic mix for diabetic and non diabetics. Asian Journal of Food Science and Technology 2013;4(10):3335.

12. James GB. Food Processing Handbook. Edited by James G. B. Wiley-VCH Verlag $\mathrm{GmbH}$ and Co. KGaA, Weinheim 2005, 27.

13. Leelavathi K, Rao PH. Development of high fiber biscuits using wheat bran: J Food Sci. Technol 1993;30(3):187-90.

14. Mayela BJ, Denisse AC, Ernesto AC, Katarzyna W, Kazimierz W, Guadalupe AG et al. Bread development with soybean, chia, linseed, and folic acid as a functional food for woman. Archivos Latino americanos De Nutricion 2007;57(1):78-84.

15. Mirasaeedghazi H, Emam-Djomeh Z, Mousavi SA. Rheometric measurement of dough rheological characteristics and Factor affecting it. Int. J Agri. Bio 2008;10:112-119.

16. Ojeka EO, Ayodele JT. Determination of chromium, copper, lead and nickel in some Nigerian vegetables oils. Spectrum 1995;2:75-78.

17. Pasha I, Butt MS, Anjum FM, Shehzadi N. Effect of dietetic sweeteners on the quality of cookies. International Journal of Agriculture and Biology 2002;4(2):245-248.

18. Raghuramulu N, Nair MK, Kalyanasundaram S. A Manual of Laboratory Technique, National Institute of Nutrition, Indian Council of Medical Research, Hyderabad, India 1993, 69-72.

19. Rangaswamy R. A Text Book of Agricultural Statistics, Second edition and New Age International Publishers. New Delhi 2010, 234-458.

20. Rao TS, Rajmanuja MN, Ashok N, Vaibhaker HS. Storage properties of whole egg powder incorporated biscuits. J Food Sci. Tech 1995;32(6):470-76.

21. Rey CE, Tecantea A, Valdivia MA. Dietary fibre content and antioxidant activity of phenolic compounds present in Mexican foxtail millet (Setaria italica L.) seeds. Food Chemistry 2006;107(2):656-663.

22. Salazar VM, Maira R, Segura C, Luis A, Chel G, David A. Antihypertensive and antioxidant effects of functional foods containing foxtail millet (Setaria italica) Protein Hydrolysates. Scientific, Health and Social Aspects of the Food Industry 2011, 382-398.

23. Shariff M, Butt M, Huma N. Oil extraction from rice industrial waste and its effect on physic-logical characteristics of cookies. Nutr. Food Sci 2005;35(6):416-27. 
24. Sharoon M, Zafar I, Atta M, Arif M, Rafiq G, Anjum R. Effect of linseed oil substituation on physic-chemical properties of cookies. J Agric. Res 2014;52(3):425-437.

25. Shiau SY, Yeh A. Effect of alkali and acid on dough rheological properties and Characteristics of extruded noodles. J Cereal Sci 2001;33:27-37.

26. Singh R, Singh G, Chauhan GS. Nutritional evaluation of soy fortified biscuits. $\mathrm{J}$ Food Sci. Technol 2000;37(2):162-164.

27. Tosco G. Los beneficios de la chíaen humanosy animales. Nutrimentos de la semilla de chíay surelación con los requerimientos humanos diarios. Actualidades Ornitológicas 2004, 1-70. 